\title{
DISTRIBUIÇÃO VERTICAL DA TAXA VOLUMÉTRICA DE PRODUÇÃO DE CALOR RADIOGÊNICO NO CRÁTON DO SÃO FRANCISCO
}

\author{
Luis Manuel García Reyes \\ Orientador: Dr. Roberto Max de Argollo (UFBA) \\ 156 p. - Tese (Doutorado) - Defesa 30.07.2008
}

\begin{abstract}
RESUMO. Neste trabalho, construímos um modelo de distribuição vertical de produção de calor radiogênico numa região do Cráton do São Francisco utilizando uma seção vertical da crosta exposta na superfície por tectonismo. Para isso, identificamos o alinhamento, na superfície, correspondente à seção vertical da crosta exposta na borda oeste do Bloco Jequié e coletamos 151 amostras de rochas em 136 afloramentos referentes às diferentes profundidades. Nos afloramentos, identificamos as litologias presentes, coletamos amostras e realizamos a localização por GPS. № laboratório, efetuamos análises químicas e petrográficas, identificamos as facies metamórficas em que se formaram as rochas, determinamos os teores dos elementos K, U e Th por espectrometria gama, a densidade, a condutividade térmica, a difusividade térmica, o calor específico e a taxa volumétrica de produção de calor radiogênico. Com base em evidências geológicas, construímos um modelo geológico por camadas no qual sugerimos ter existido uma crosta de $51 \mathrm{~km}$ de espessura nessa região, onde os primeiros $16 \mathrm{~km}$, de sedimentos e xistos-verdes, já foram erodidos, restando 7,2 km de crosta na facies anfibolito superposta a 27,8 km na facies granulito. Nesse modelo, as unidades geológicas charnoquitos ("A"), enderbitos ("B"), granitos ("C") e tonalitos ("D") estão presentes no alinhamento, as duas primeiras na facies granulito e as duas últimas na facies anfibolito, constituindo duas seções verticais expostas da crosta "C"-"A"-"B" e "C"-"D"-"B". Mostramos, ainda, que as rochas nessas seções foram afetadas por um segundo episódio de deformação isoclinal com planos axiais mergulhando $30^{\circ} \mathrm{E}$ e que as regiões centrais das unidades enderbíticas e tonalíticas correspondem a antiformes desse segundo episódio. Assim, à medida que percorremos as seções "C"-"A"-"B" e "C"-"D"-"B", estamos caminhando na vertical da crosta. Elaboramos um modelo de decrescimento exponencial da taxa de produção de calor radiogênico com o aumento da profundidade que considera um comportamento diferente em cada facies metamórfica. Nesse modelo, constatamos que essa grandeza é influenciada tanto pela litologia quanto pela profundidade crustal, sendo aquele o mais determinante. Para cada facies, em cada seção, definimos uma função exponencial de decaimento da taxa de produção de calor o que nos permitiu calcular a contribuição do calor gerado na crosta para o fluxo de calor na superfície. Na região "C"-"A"-"B" essa contribuição é de 51,9 mWm², enquanto na região "C"-"D"-"B" de 49,4 mWm-2. Aplicamos as equações obtidas para avaliar a contribuição do calor radiogênico para o fluxo de calor total na crosta das bacias de Camamu e Almada. Essas bacias também pertencem ao Cráton do São Francisco e possuem uma crosta na facies granulito com espessura estimada em $30 \mathrm{~km}$. A contribuição encontrada foi de $30,6 \mathrm{mWm}^{-2}$ e o fluxo térmico na base da crosta de $19,9 \mathrm{mWm}^{-2}$.
\end{abstract}

ABSTRACT. In this work we propose a model for the vertical distribution of radiogenic heat production in the region of São Francisco Craton. A vertical cross-section of the crust exposed at the surface by tectonism was used. For that a detailed geologic profile was performed at the west border of Jequié Block. Along this profile we collected 151 samples of rocks in 136 outcrops related to the different crustal depths. At the outcrops we identified the lithologies, collected samples and indicated in the location using GPS. At the laboratory we performed chemical and petrographic analysis, identified the metamorphic facies under which the rocks were formed, and established the content of the elements $\mathrm{K}, \mathrm{U}$ and Th by gamma ray spectrometry. In addition we measured the density, the thermal conductivity and diffusivity, the isobaric specific heat and then computed the volumetric ratio of radiogenic heat production. Based on geologic evidences we built a geologic layered model for that crustal block. From this model we suggest a crust $51 \mathrm{~km}$ thick in this region, where the first $16 \mathrm{~km}$ of sediments and greenschist facies were already eroded, remaining $7,2 \mathrm{~km}$ of amphibolitic facies superposed to $27,8 \mathrm{~km}$ of granulitic facies. In this model the geologic units charnockite ("A"), enderbite ("B"), granite ("C") and tonalite ("D") are present at the profile. The first two were metamorphized at the granulite facies whereas the others at the amphibolite facies, forming two exposed vertical cross-section of the crust "C"-"A"-"B" and "C"-"D"-"B". We infer that the rocks in these sections were affected also by a second episode of isoclinal deformation with axial planes dipping $30^{\circ} \mathrm{E}$ and that the central regions of enderbitics and tonalitics units correspond to antiforms of this second episode. Thus, as we go through the sections " $\mathrm{C}$ "- $\mathrm{A}$ "-" $\mathrm{B}$ " and "C"-"D"-"B", we are walking at the vertical along the crust. We propose a model of exponentially decreasing radiogenic heat production with increasing depth that has a different behaviour in each metamorphic facies. In this model we evidenced that this magnitude is influenced by lithology and by the crustal depth, the first being the most determinant. For each facies along the two sections we defined a exponential function of decreasing of heat production rates. This allowed us to compute the contribution of heat generated at the crust for the surface heat flow. In the region "C"-"A"-" $\mathrm{B}$ " this contribution is of $51,9 \mathrm{mWm}{ }^{-2}$, while in the region "C"-" $\mathrm{B}$ "-"B" it is of $49,4 \mathrm{mWm}^{-2}$. The obtained equations were employed to evaluate the contribution of radiogenic heat to the total heat flow at the crust under the Camamu and Almada basins. Those basins are also part of the São Francisco Craton and have a crust at the granulite facies with an estimated thickness of $30 \mathrm{~km}$. The identified contribution was of $30,6 \mathrm{mWm}^{-2}$ and the heat flow from the upper mantle of $19,9 \mathrm{mWm}^{-2}$. 